Goca D. Jovanović ${ }^{1}$

Slavko Božilović

University UNION Nikola - Tesla, Belgrade
SCIENTIFIC REVIEW ARTICLE doi:10.5937/ekonomika1701097J

Received January, 30, 2017

Accepted: March, 13, 2017

\title{
THE INFLUENCE OF MANAGEMENT OF HUMAN RESOURCES ON MOTIVATION AND JOB SATISFACTION
}

\begin{abstract}
Major changes in recent years have affected the work of the organization. Successful business requires great flexibility, accountability and speed of product development and services. In the heart of the success of the organization, to achieve the mission and vision, lies highly qualified staff that is motivated, loyal and concentrated on achieving the objectives. Motivation is the effect that causes, directs and maintains the desired behavior of people. Human resources are the most creative and driving force of the organization. The level of training for work, working habits, level of responsibility and the quality of the relationship to work, their motivation and creativity depend on the future performance of the organization. Construction quality motivational system can increase the competitive ability and value of the organization. Job satisfaction is related to a positive emotional reaction and attitudes of employees towards their work. Job satisfaction significantly affects the efficiency and effectiveness of employees. This paper presents the results of research and analyzed the impact of human resource management on motivation and job satisfaction in the public sector.
\end{abstract}

Key words: human resources, motivational factors, theories of motivation, motivation and job satisfaction.

JEL classification: M21, M54

\section{UTICAJ MENADŽMENTA LJUDSKIH RESURSA NA MOTIVACIJU I ZADOVOLJSTVO POSLOM}

\begin{abstract}
Apstrakt
Velike promene tokom poslednjih godina uticale su na rad organizacija. Uspešno poslovanje zahteva veliku fleksibilnost, odgovornost i brzinu razvoja proizvoda i usluga. U srcu uspešnosti organizacije, ostvarenja misija i vizija, leži visokokvalifikovano osoblje koje je motivisano, odano i koncentrisano na postizanje ciljeva. Motivacija je uticaj koji izaziva, usmerava i održava željeno ponašanje ljudi. Ljudski resursi predstavljaju najveću pokretačku i stvaralačku snagu organizacije. Od stepena njihove osposobljenosti za rad, razvijenosti radnih navika, nivoa odgovornosti i kvaliteta odnosa prema radu, njihove motivisanosti i kreativnosti zavise buduće performanse organizacije. Izgradnja kvalitetnog motivacijskog sistema može povećati konkurentsku sposobnost $i$ vrednost organizacije. Zadovoljstvo poslom se odnosi na pozitivnu
\end{abstract}

\footnotetext{
${ }^{1}$ g.jovanovicbg.@gmail.com

${ }^{2}$ rektor@unionnikolatesla.edu.rs
} 
emocionalnu reakciju i stavove zaposlenih prema svom poslu. Zadovoljstvo poslom u znatnoj meri utiče na efikasnost $i$ efektivnost rada zaposlenih. U ovom radu izneti su rezultati istraživanja $i$ analiziran uticaj menadžmenta ljudskih resursa na motivaciju $i$ zadovoljstvo poslom u javnom sektoru.

Ključne reči: ljudski resursi, motivacioni faktori, teorije motivacije, motivacija $i$ zadovoljstvo poslom.

\section{Introduction}

In today's business, market conditions, everyday technological and economic changes contribute to the economy with new business challenges, which have arisen as a result of a dynamic market environment. An increasing number of organizations achieves a competitive advantage thanks to the quality of human resources. Human resource management is considered a key activity management, whose mission is to provide quality workers, reduce operational costs through effective recruitment, takes account of the needs of employees and manages complete administration regarding the relationship of the organization to employees and their position. "Management of competent people requires constant balance between human aspirations and meeting strategic and financial needs of the business" (Torrington, Hall, Taylor, 2008).

Work motivation proved to be one of the most important prerequisites of work efficiency and achieving the targets of both individuals and the entire organization. Percentage of motivation in organization is directly proportional to the quality of the results achieved and the level of development of the organization. Every manager wants to have a large number of motivated individuals and groups in your organization, which is of great importance in a planned and systematic work to improve the morale and motivation of employees, which in turn largely falls within the scope of work of experts in human resource management (Đorđević-Boljanović, Pavić, 2011, p. 252).

In keeping with the theme of work, we will deal with research and analysis of the impact of human resource management in the public sector employees and the presentation of the decisive factors that influence the motivation and job satisfaction of employees in public institutions in Pancevo. This research highlights all the more topical phenomenon of motivation and its undeniable impact on improving the quality of working life of employees, but also to increase their working engagement. The goal is to determine the level of motivation of employees in the public sector, including analysis of all significant aspects of work motivation and context of the transaction, which would symbolically pointed to a current picture of the general state of satisfaction and a certain way to identify the factors that are the primary source of employee dissatisfaction at work. The scientific objective of this paper is to highlight the importance of the contribution and activities of human resource management as a scientific discipline and business functions to achieve the organization's goals, as well as the motivation of employees to achieve these goals by his conduct, which reflects a good quality business.

The structure of the work, in addition to the introductory part and conclusion, it consists of four parts. In the first part the attention is paid to the factors of motivation to work, or 
motivators and demotivators. The second part is a theory of motivation, theory of motivation content and process theories of motivation. In accordance with the present concepts and theories are given concrete examples and guidelines that managers can be useful for initiating and directing the behavior of people at work. In the third part of the paper we emphasized the specifics of motivation, productivity and job satisfaction as individual categories and discuss their mutual interaction. Mutual link these relations is a matter for the analysis of the impact of job satisfaction has on employee motivation, and motivation level of impact on work efficiency. In the third part of the survey is analyzed and interpreted the results of research on the case of the public sector in public institutions in Pancevo, as well as the conclusions that can be drawn from it.

\section{Theories of motivation to work}

Theories of motivation can be divided in different ways, but the most famous is the division into two basic groups: the theory of motivational content and process theories of motivation. The theory of motivation emphasize the content needs of the people, and emphasis on the motives that employees strive to achieve in organizations. Theories of motivation process focused on the processes and methods by which managers are encouraged satisfaction among employees.

According to Maslow's theory of needs (Ivancevich, Lorenzi, Skinner, Crosby, 1997), people in the organization runs five primary needs which are hierarchically sorted, so that an individual to meet the needs of more hierarchical be crossed only after satisfying the needs at a lower level. These needs are physiological or existential (needs that each individual has as a biological being - the need for food, water), security needs (the need for the physical and psychological safety - protection against external hazards, health care, protection of personal integrity, pension and social insurance), social needs (need for love and friendship and a sense of belonging), the need for respect and self-esteem (need for respect by others, as well as self-esteem, which derives from each other) and the need for actualization (the need for personal development, self-actualization and realization of all their capabilities, talents and full potential).

Modification of Maslow's theory of motivation represents Alderfer ERG theory (Hellriegel, Jackson, Slocum, 2002) which contains three types of needs that are not listed hierarchically, and they include: basic needs (need for food, air, water, certain benefits and adequate working conditions), the need for connectivity (for the purposes of placing and maintenance good interpersonal relationships with co-workers, superiors, friends and family) and development needs (need for personal development and personal advancement usavršavaljem). His opinion is that when a person satisfying the needs of a higher level, then the person begins to invest double efforts to the needs of lower level.

McClelland's theory (Wright, Noe, 1995) of needs is exclusively focused on work motivation and work behavior explains the importance of individual motives, which is considered fundamental, objective of the awards is a sense of satisfaction and pride. According to this theory, there are three groups of factors that affect the satisfaction of employees in the organization: the need for power (desire for influence and control over the people, as well as over their affairs, activities and tasks), the need for achievement (the tendency of an individual employee or to achieve success in the work place) and the need for the association 
(aspirations to friendly relations, cooperation and human relations based on high trust and understanding), (Petković, 2009).

Motivation - hygiene theory, or the theory of two factors, based on factors work in combination with working conditions. Motivation - hygiene approach also represents a modified version of the theory of necessity. Unlike Maslovljevog views and orientation to the needs of people Herzberg is his research (Hellriegel, Jackson, Slocum, 2002) showed that satisfaction and dissatisfaction are not opposite ends of the same continuity, but there are two completely different dimensions: satisfaction in relation to the lack of discontent and dissatisfaction in relation to the lack of satisfaction. In addition, Herzberg's factors influencing satisfaction called motivation, and factors that encourage discontent called hygiene (Pavić, 2011, p. 65).

To understand the theory of two factors, it is important to stress that, in practice, quite understandably, factors affecting the dissatisfaction can not cast you forth, and that their existence in companies inevitable. On the other hand, Herzberg's assertion (Hellriegel, Jackson, Slocum, 2002) that through job enrichment can be achieved by motivating employees was often criticized. It is believed that this view influenced the simplified understanding of the categories of satisfaction and dissatisfaction, which this theory gained a lot of critics, but also supporters. If we accept this theory as valid, then the task manager is primarily related to the provision of organizational conditions and encouraging inner motivator in employees, primarily non-financial forms of remuneration.

Goal-setting theory has defined Edwin A. Locke (Lock,1968). According to him, motivate employees three mechanisms: a specific and clearly defined objective, InformationLa feedback on the achievement of set goals and employees' participation in setting goals. The goal will motivate the individual or the employee, if clearly defined, if it is harder but if desirable and achievable. If goals are unattainable and too heavy, it can be counterproductive, and it is necessary that the employees themselves participate in defining the objectives, it will be easier to accept and consequently implemented.

The theory of equality or justice (Adams, 1965) is based on the constant comparison of employees with collective. Employees are very important as far as they themselves are rewarded for our work and effort, but they more importantly how many others have been awarded for the same work. When employees realize that there is inequality and to challenge injustice, then comes to the creation of tension, which is a signal for managers to change the work environment and business policies to ensure an equitable relationship among employees. According to this theory, in addition to wages, the factors that are compared are: status at work, physical work conditions, technical equipment of the workplace, employee involvement in decision-making and the like.

Expectancy theory (Vroom, 1964) is based on the assumption that most of the behavior of individuals, organizations and employees in the fruit of their free choice. Expectations Model consists of three important related components: behavior-outcome valence and effort-result. According to this theory, individuals are motivated to understand that there is a favorable combination of what is important for them and what they expect as a reward for the hard work and then behave in an appropriate manner (Čerović, 2013, p. 217-218). 


\section{Motivation for work, labor productivity and job satisfaction}

People, their needs, motivation, productivity and job satisfaction of becoming the center of attention of human resource management, as it became clear that human capital is the main tool of competitive abilities and strengths in the global market. Motivation can be defined as a set of factors that drive and guide people and encourage them to persevere in their efforts to achieve a specific goal (Villiams, 2011, p.232). People who are committed to the organization in which they work, they are ready to fight for the realization of its goals and feel satisfaction over the progress of the organization (Đorđević-Boljanović, Dražeta, Babić, Dobrijević, 2013, p.253). To operate successfully, every organization needs to find an optimal combination of material and non-material incentives for their employees, which depends on many factors: the sector in which it operates, competition in the labor market, the nature of the transaction structure. Tangible motivation is under the direct influence of the organization, its policies and practices. Immaterial incentives involve employees more active role in taking responsibility for improving operations and powers on major business decisions (Čerović, 2013, p.212). To ensure adequate quality of employees in organizations, it is necessary to offer an adequate level of earnings, which is only a necessary condition, but not sufficient.

If you really want to motivate someone, we have to understand their needs and goals. In the first phase of the motivational process is the formation of motives, or that activities of the employee towards the achievement of a specific goal. In the second phase, these activities produce a certain effect, but in the third there is employee satisfaction effect, as the logical consequence of the effect of certain awards. It is assumed that employee satisfaction effects of their own work, or the award reproduces motive and thus closes the circle, a motivational process starts again (Čerović, 2013, p. 209). Motivational drivers are factors that are essential for the success of the changes, and they are: a clear vision, unified and decisive team implementing changes, education of participants and communication with all those who at various levels should implement changes, or that their resistance can them huts. Motivation in the organization is fostering and causing the will to work and work performance. Active people and their behavior has been encouraged by certain causes and goals that arise as a stimulus to creativity or initiative motives or actions. The motives are psychological factors that drive the activity, direct and maintain activity for achieving the objective that can meet specific needs (Kordić, Pajević, 2007). According to the origin of the motifs are divided into biological and social, according to a source in the external and internal (Mašić, 2010, p. 341). The award is an external motivator that influences the man to re-apply some form of behavior in order to achieve the same effect. Internal motivators are related to the complacency of the performance of certain activities (Mašić, 2009, p. 329). Motivation is closely related to the will and therefore unpredictable. Particularly interesting are the three characteristics of motivation: encouragement, guidance and strength (Mitchell Daniels, 2003). Motivation is influenced by many factors: individual characteristics, job characteristics and the characteristics of the company (Čerović, 2013, p. 207).

Productivity as one of the most important criteria of efficiency of labor depends not only on the established social relations but also on ways of organizing work and business. When productivity in the narrow sense takes only one factor - labor (Barać, Stakić, 2008). By tracking employee productivity organization basically accomplishes two main objectives (Pržulj, 2007, p. 299): 
1) Increasing the level of commitment of the employees at work - motivational potential of this process stems from the feedback on the results of the employee (the need for self-realization), as well as the recognition result (the need for respect). In addition, this process can indicate valuable message to employees on how to evaluate and respect their work.

2) Establishing a plan for future development of employees - monitoring and performance evaluation of working allows employees to have a clear idea of what is expected of them and what results were achieved. Individuals wishing to obtain information about their work - which is the basis for obtaining a just reward, job security, professional development and career planning.

To understand the cause-posledničkog relationship of motivation and labor productivity, in terms of organization must be assumed that the motivational component especially important. Specific features of motivation contribute to the shaping of this relationship in a way that suggests that productivity as a goal depends on the motivation of such funds. This means that when productivity increases, it is expected to grow and motivation, because motivation is followed by productivity or productivity precedes motivation.

In many of our organizations, there is no continuous measurement of motivation and employee satisfaction. Measuring motivation is possible by using three basic techniques: interviewing workers, evaluating the behavior of workers and performance measurement (Čerović, 2013, p. 213). The motivation for the work is related to the topic of job satisfaction, job satisfaction also has been associated with creativity, and enhancing motivation and promotes creativity, the creative energy assessments that give pleasure and joy of life. Creativity and satisfaction are related aspects of labor (Jovičević, 2010).

The problem of motivation and employee satisfaction becomes particularly significant in terms of the current transitional changes. The upcoming market transformation organizations require secure the achievement of a number of preconditions, among which the important place occupied by the establishment of the new system of motivating employees, based on continuous measurements to customer satisfaction, and motivation of employees. Measuring employee satisfaction is an unavoidable part of the process of organizational management for positioning the organization as a whole and its organizational units that work in strategic analysis and strategic choices. Under employee satisfaction involves a subjective assessment of the degree of satisfaction arising from the assessment of personal satisfaction with various aspects of their loyalty to the organization. Employee satisfaction primarily relates to the perception of employees and the degree to which they met their motives, a first motives which are seen as important for their engagement. Understanding employee satisfaction is essential for a more complete understanding of the effects of variations of incentives and motivation of employees, particularly if they are relevant to employee satisfaction. Measuring employee satisfaction should always be accompanied by measurement of employee motivation. These two systems of measurement are performed simultaneously. We should bear in mind the basic assumption that the motivation is always at the center of employee satisfaction.

\section{Research methodology}

Human resource management has long been an important link in modern business. The basis of quality labor organizations are employed. Employee satisfaction has a huge 
impact on their results, as well as the success of the organization. For a successful business requires analysis of business, human resource planning, recruitment and selection, training and development of employee skills, career development, promotion, rewarding and motivating employees.

The subject of the research is to describe the impact of human resource management in the public sector employees and see the decisive factors that influence the motivation and job satisfaction of employees in public institutions in Pancevo.

The research in this paper provides answers to the following questions:

- How many employees are satisfied with cooperation with their colleagues at work and interpersonal relationships?

- Have employees participate in some segments as a team to achieve mutual outcomes and improving the quality of business?

- The extent to which employees are satisfied with working space in the service?

- Do staff have the necessary equipment and materials for the proper and timely performance of work?

- Are employees satisfied with monthly income?

- Do employees believe that salaries should be higher taking into account the work they do?

- Are employees satisfied with regular cash income?

- Are staff in the past month received verbal recognition for a job well done?

- Are employees rewarded financially during the year for a successful job?

- Do staff have the chance to advance in the coming year?

- How many employees are satisfied with investment in professional training (professional meetings, postgraduate studies, foreign languages) for successful work in the organization?

- How satisfied are opportunities to put your ideas about improving the quality of work put forth superiors?

- Do staff have a sense of job security in the current workplace?

- Would you change your job, or from the public sector to the private proceed?

- Are public sector employees motivated and satisfied with the work they perform?

This research can help to give a true picture of business in the public sector and to emphasize the importance of the contribution and activities of human resource management as a scientific discipline and business functions to achieve the organization's goals, as well as the motivation of employees to achieve these goals by his conduct, which is reflected in good and quality work. The importance of the research is realized in the reflection of the current state of employee satisfaction, while the results suggest that indicators need to be improved for better functioning of the public sector, providing quality products and services.

\section{Survey instruments}

The survey was conducted from 15 march to 20 june 2016 in the public sector, in public institutions in Pancevo. Participation of employees in the survey was voluntary and anonymous, which is fully secured protection of personal data on employees. For the study used a structured questionnaire, designed so that the first questions relating to demographics, 
followed by studied categories of employee satisfaction, which are organized as sets of assertions. Questions are closed, and the respondents were able to express their agreement or disagreement with respect to the given claims. The survey consists of 15 questions. Questions were ranked marks from 1 to 5 , where 1 means completely disagree, 2 disagree, 3 am indecisive, 4- agree, a 5- completely agree. The survey is tailored case studies and indicators included in the assessment of pleasure at work are: the satisfaction of material income, reward system, relations with co-workers, promotion, personal development, job security and overall satisfaction. The data is subsequently processed and analyzed as follows: the application of statistical techniques with numerical indicators, interpretation of results, putting emphasis on incentives within which there is a significant difference between the degree of their importance and satisfaction. All of this will make sense when we know that the best use of the obtained information, information about job satisfaction, and how to bring them under the most correct decision.

\section{Analysis of survey research staff with discussion}

The study included 100 respondents employed in the public sector during the period from 15 march to 20 june 2016. in public institutions in Pancevo. Given the fact that the public sector is closed in terms of wages, thinking about your position at work and other elements that contained a questionnaire, was the only way to get results. It was found that the employees have the following general characteristics:

- Gender structure of employees - from a total of 100 respondents was fortified to make the 43 respondents, or $43 \%$ of males and 57 form the respondents, or $57 \%$ of the female gender.

- Structure of employees by age - to determine the age structure were determined intervals respondents: 30 years, 30 to 50 years and for over 50 years. On the basis of the research, it can be stated that in the public sector most represented age group over 50 years, which the 59 respondents, or $59 \%$, followed by the age group of 30 to 50 years, which the 39 respondents, or $39 \%$ of the age group to 30 years, which the two respondents, or $2 \%$.

- Employee-structures based on qualifications - examination it was determined that the largest group consists of employees with VII level of education, ie university graduates, 53 of them, or $53 \%$. Employees with VI level of education has a 9 or $9 \%$, while employees with IV level of education has a 38 or $38 \%$.

- Employment structure by years of service - to determine the structure of the employees are determined intervals of service - category up to 5 years, from 5 to 10 years, from 11 to 20 years and over 20 years. On the basis of the research, it can be stated that in the public sector, the most common category of over 20 years of service, which the 45 respondents, or $45 \%$, then the category of 11 to 20 years, which the 37 respondents, or $37 \%$, while the category of 5 to 10 years belonging to 16 patients, or $16 \%$, and the category of up to 5 years of service belonging to two respondents, or $2 \%$.

In the text below we analyze the questions contained in the survey response rates and comments received from respondents.

1. To the question: "How much are you satisfied with the cooperation with colleagues at work and interpersonal relationships?", Most of them responded that they are satisfied - 67 
respondents, or $67 \%$, while 33 of them, or $33 \%$, said they were dissatisfied. Based on these results it can be concluded that employees are satisfied with cooperation with their colleagues at work and interpersonal relationships, which creates a positive working atmosphere, an atmosphere of teamwork and positive impact on the work of the entire public sector.

2. To the question: "Did you participate in some segments as a team to achieve mutual outcomes and improving the quality of business?" Most answered that they participate in teamwork in order to achieve joint results - 53 respondents, or $53 \%$, while 37 of them, or $37 \%$, responded to the contrary. Based on these results, we can conclude that the majority of respondents satisfied with participation in teamwork to achieve common results, which creates a positive working atmosphere and has a great impact on the quality of products and services of the public sector.

3. To the question: "To what extent are you satisfied with the working space in the service?", Most of them responded that they are satisfied - 59 respondents, or 59\%, while 35 of them, or 35\%, responded neither unhappy nor dissatisfied, and 6 patients and $6 \%$ said they were dissatisfied. Based on these results, it can be concluded that employees are satisfied with working in the service area, which creates a positive working atmosphere and positive impact on the work of the entire public sector.

4. To the question: "Do you have the necessary equipment and materials for the proper and timely performance of work?", The majority of respondents, $83 \%$, or 83 , said they have all the necessary equipment and materials for the proper and timely performance of work at the workplace, while 17 respondents or $17 \%$ said the opposite - it does not have all the necessary equipment and materials for successful job performance. This can be a very important factor for the work and productivity of employees, as $17 \%$ or 17 respondents, or thinks he does not have all the necessary equipment and materials for activities and jobs, which can be the cause of their dissatisfaction and lack of motivation to do their jobs. For the public sector the prevailing opinion is that all workplaces equipped to a large extent, and even excessive for the performance of certain business activities. However, in the public sector there are a large number of jobs related to the direct production of goods and services, as well as the jobs of maintenance of electrical installations, telefenskih and Internet installation. If employees at these workplaces have all the necessary equipment, it will extremely affect their productivity and satisfaction with the performance of a specific task.

5. To the question: "Are you satisfied with monthly income?", Most of them responded that they are satisfied - 56 respondents, or $56 \%$, while 44 of them, or $44 \%$, said they were dissatisfied. This result breaks the prejudice about that in the public sector, high salaries, because there are parts of the public sector such as education, health and police, where wages are below the national average. It could be said that more than half of employees are satisfied with their salary because it is above the national average. The results can be interpreted in such a way that even the average wage does not provide a normal and peaceful life, but employees constantly strive to increase their wages. Wages in the public sector are certainly not as much as would employees want, but they are above the national average. However, the fact that wages are above the national average does not mean that employees should be satisfied. This result can be viewed from different angles, with respect to that salary is not the only motivating factor for employees. From the standpoint of human recourses, this result can be interpreted as problematic in motivating employees, but due to the constant tendency of employees to higher earnings, this is not the key factor of motivation for employees in the public sector. 
6. To the question: "Do you believe that salaries should be higher taking into account the work you do?", The majority of respondents, 78 , or $78 \%$, responded that they thought should have higher wages due to work performing, while 22 of them, or $22 \%$, responded to the contrary. This large number of public sector employees who feel that they deserve a higher salary can be interpreted from different perspectives. First of all, there is a tendency for people to make more money, but it is very important and the general economic situation in the society, which is characterized by usually low salaries. So that even though $78 \%$ of employees are satisfied with the salary he receives, some employees considered that deserves greater. This indicator is for the management of human resources is more important than the previous question, given that more points to dissatisfaction of employees earnings, or the perception of the amount of earnings in relation to the weight and volume of work they do. On the other hand, only $22 \%$ of respondents believe that their salaries should not be increased due to the work they do, so it can be assumed that the employed with relatively high incomes for our economic circumstances or on employees who actually perceive the weight of your work and the amount of their salary and have a realistic comparison of their salaries and their work with the salaries of other employees who perform other tasks they probably considered more difficult and complex.

7. To the question: “Are you satisfied with regularity plate?", The majority of respondents, 97 , or $97 \%$ responded positively, while $3 \%$ of them, or 3 respondents answered negatively. Given the fact that wages in the public sector has long been regular, the fact that the majority of employees satisfied with regularity of payment of wages is not at all surprising. If the employees in the public sector is one of the most important factors of motivation regular payments of salaries, then this is a great result for human resources, due to the fact that one of the main factors influencing the motivation of staff met to the fullest extent, and that for the sake of increasing motivation employees should turn to other factors that influence to ensure that employees are motivated.

8. To the question: "Are you in the past month received verbal recognition for a job well done?", The majority of respondents, 56 , or $56 \%$, declared that in the last month received a verbal commendation for a job well done, while 44 respondents or $44 \%$, did not receive a verbal praise for a job well done. Given that, on the basis of the results obtained, the same number of respondents received a verbal recognition, it can be concluded that it is not enough when the motivation of the employees concerned. As it is known, is one of the most important factors of motivation did praise the master to successfully perform the job.

9. To the question: "Are you financially rewarded during the year for a successful job?", 29 respondents or $29 \%$ said yes, while 71 respondents, or $71 \%$ gave a negative answer. As it is desirable from the standpoint of motivation of employees, more employees should receive verbal praise for successfully carried out a job, but more importantly in this day and age that their work be successful and financially evaluated. The more employees being rewarded, it will be higher employee satisfaction. The best way for everybody to be satisfied is that the whole process of awarding cash prizes and bonuses, and possibly also the evaluation, to be as transparent and accessible to all employees, which will prevent employee dissatisfaction.

10. To the question: "Did you have a chance to advance in the next year?", 29 respondents or $29 \%$ said they expected a chance to advance in the coming year, while 49 respondents or $49 \%$ said they do not expect promotion in the coming year. The answer "do not know" gave 22 respondents, or $22 \%$. Given the fact that the possibility of promotion is an important factor of motivation of employees, as well as concern may be taken obtained 
information that nearly half of employees do not expect any opportunity for advancement, and even $22 \%$ of respondents do not know whether you will get any chance. The task of human resources in the public sector is to examine why such a small number compared to all employees expected to have a chance for advancement, as well as to investigate why $22 \%$ of employees do not expect or does not know whether it will get that chance.

11. To the question: "How satisfied are you investing in professional training (professional meetings, postgraduate studies, foreign languages) for successful work in the organization?", The majority of respondents, 52 , or $52 \%$, responded that they were satisfied, 32 respondents or $32 \%$ responded that they were dissatisfied, while 16 respondents or $16 \%$ said they were not satisfied nor dissatisfied. Based on these results, it can be concluded that employees in the public sector are satisfied by investing in professional training.

12. To the question: "How satisfied are you with the conditions and possibilities to put your ideas about improving the quality of work bring up superiors?" Most respondents answered they were satisfied, 48 of them, or $48 \%, 32$ respondents or $32 \%$ said they were dissatisfied, while 20 respondents or $20 \%$ said they were neither satisfied nor dissatisfied. Based on these results, it can be concluded that employees in the public sector that pleased with their ideas about improving the quality of work put forth superiors.

13. To the question: "Do you have a sense of job security in the current job?", The majority of respondents, 45 , or $45 \%$, pleaded feel confident about their current job, while 35 respondents or $35 \%$ responded that their job is not considered safe, while 20 respondents or $20 \%$ said they did not know whether their workplace is safe, or that they do not know whether to consider it safe or not. Based on these results, we can conclude that there has been a significant change, given that the earlier the public sector went into retirement, but today this is not the case. In this case, fear of job works on motivating employees, because in order to keep their job and position, must strive to work more productively.

14. To the question: "Would you change your job, or from the public sector to the private proceed?", The majority of respondents, 46 , or $46 \%$, responded that certainly would not have changed jobs and moved to the private sector, followed by 42 respondents, or $42 \%$ responded that under certain conditions may be moved from the public to the private sector, while 22 respondents, or $22 \%$, is not at all sure whether they would change jobs and under what conditions. It is this balance in the answers on the transition from the public to the private sector gives a picture of human resource management that neither the public sector is no longer the most desirable place to work and motivational factors should be given great attention, in some cases because of dissatisfaction would not have been a significant transition highest quality employees from the public to the private sector, which would decreased the quality of products and services that the public sector provides.

15. To the question: "Are public sector employees motivated and happy with the work that they carry out?", The majority of respondents, 59 , or $59 \%$, responded that they were satisfied, 32 respondents or $32 \%$ said they were dissatisfied, while 9 respondents, or $9 \%$, reported that they are neither satisfied nor dissatisfied. Based on these results, it can be concluded that the public sector employees motivated and satisfied with the job they do, which creates a positive working atmosphere, an atmosphere of teamwork and a positive effect on the operation of the entire public sector. 


\section{Conclusion}

Modern public sector does business in more complex terms, conditions which forced him to continually reviewing and improving its business policy. Public institutions must be prepared to effectively respond to new requirements arising in the market, but also to effectively cope with all the dangers that are present every day. It can be concluded that human resource management as a scientific discipline and the business function has a specific task in the public sector to establish a balance between the objectives and the needs of employees and the goals and needs of individual authorities and institutions in the public sector. The quality of public services is increasingly dependent on competencies of employees who implement the core activity. Therefore, the position of human resources required to develop new policies to recruit and retain the necessary skills for public service with high efficiency. In order to adapt human resources to current and future needs of the public institutions in Pancevo, it is necessary continuing education of employees.

Incentives and motivation theories have a strong role in motivating employees to achieve their own and organizational goals. For public sector employees as a motivation factor most affecting the regularity of income and career prospects. Regularity of income is the most important factor of motivation, a great impact recorded the opportunity for advancement. In contrast, studies have shown that employees are not motivated so much job security, at least not the majority of employees in the public sector. Based on the research results, the employees are properly motivated to perform duties and tasks. Public sector employees have completed all the tangible and intangible prerequisites for successful work and provide quality products and services, from the regularity and level of income through promotion, through oral and cash awards for successful work. This makes them motivated to perform their duties well and what better way to raise the reputation of the public sector. The public sector is increasingly used modern techniques and human resource management policies to employees prepared and successfully motivated to do the job.

Contemporary public institutions develop fully in line with how much to invest in their employees and how to inspire. Therefore, it is especially important to the proper motivation, the introduction and use of a motivator in the workplace and with good personal communication at all levels to improve performance and productivity. The basic recommendation is to keep the good results in the areas in which it was noted that the employees are satisfied. However, at the same time be effective to work on improving results in areas where it was shown that there is a possibility for improvement. In order to encourage full engagement of employees, it is necessary to determine the true ways of their motivation and interest in work and more successful business. Investment in human resources and the motivation to work is justified by the cost of which is still more than repaid. Weather front of us increasingly expanding range of knowledge necessary for successful use of resources, the fundamental conditions for a successful business.

\section{References}

Torrington, D., Hall, L., Taylor, S. (2008). The nature of human resource management, Harlow, Pearson Education Limited, p.4. 
Đorđević-Boljanović, J.,Pavić, Ž.(2011).Osnove menadžmenta ljudskih resursa,Beograd.252.

Ivancevich, J.M., Lorenzi, P., Skinner, S.J., Crosby, Ph. B. (1997). Management- Quality and Competitiveness, Boston, 319, adapted from Maslow A.H. (1943). A Theory of Human Motivation, Psychological Review 50, 319.

Hellriegel, D., Jackson, S. E., Slocum, J. W. (2002). Menagement, A Competency - based Approach, South-Western Thomson Learning, Canada, 393.

Wright, M.P., Noe, A.R. (1995). Management of Organizations, McGraw-Hill, New York, 367.

Petković, M. (2009). Organizaciono ponašanje, Beograd, Ekonomski fakutet.

Hellriegel, D., Jackson, S.E.A., Slocum, J.W. (2002). Management, Canada, 385.

Pavić, Ž. (2011). Etika i poslovne komunikacija, Beograd, 65.

Lock, E.A.(1968). Toward a Theory of Task Motivation and Incentives. Organizational Behavior and Human Performance, 3, 157-189.

Adams, J.S. (1965). Inequity in social exchange, In L. Berkowitz (Ed.), Advances in experimental social psychology, Vol. 2, 267-299, New York, Academic Press.

Vroom, V.H. (1964). Work and motivation, New York: Wiley.

Čerović S. (2013). Upravljanje ljudskim resursima u hotelijerstvu, Beograd, 217-218.

Villiams, C. (2011). Principi menadžmenta. Beograd, Data Status, 232.

Đorđević-Boljanović, J., Dražeta, L., Babić, L. Dobrijević, G. (2013). Razvoj karijere i poslovnih veština. Beograd,253.

Čerović S. (2013).Upravljanje ljudskim resursima u hotelijerstvu, Beograd, 212.

Čerović S. (2013).Upravljanje ljudskim resursima u hotelijerstvu, Beograd, 209.

Kordić, B., Pajević, D. (2007). Opšta psihologija sa socijalnom psihologijom, Centar za primenjenu psihologiju, Beograd, 108.

Mašić, B. (2010). Menadžment - Principi, koncepti i procesi. Beograd, 341.

Mašić, B. (2009). Menadžment - Principi, koncepti i procesi. Beograd, 329.

Mitchell, T.R., Daniels, D. (2003). Motivation, in: Weiner, I.B.(ed.) Industrial and Organizational Psychology, John Wiley \& Sons, Inc., Hoboken, New Jersey, 226.

Čerović S. (2013). Upravljanje ljudskim resursima u hotelijerstvu, Beograd, 207.

Barać, S., Stakić, B. (2008). Osnovi ekonomije, Beograd, 105.

Pržulj, Ž. (2007). Menadžment ljudskih resursa, Beograd. 299.

Čerović S. (2013). Upravljanje ljudskim resursima u hotelijerstvu, Beograd, 213.

Jovičević, M.(2010). Kako ostvariti zadovoljstvo poslom, Beograd. 